\title{
FAKTOR-FAKTOR YANG MENYEBABKAN PERMASALAHAN RELOKASI BANTARAN SUNGAI (STUDI KASUS: KAMPUNG PULO KE RUSUNAWA JATINEGARA BARAT)
}

\author{
Rani Chien Silalahi ${ }^{1}$ \\ ${ }^{1}$ Mahasiswa Magister Teknik Perencanaan, Universitas Tarumanagara, Jakarta \\ E-mail:chien_silalahi@yahoo.co.id
}

\begin{abstract}
ABSTRAK
Salah satu bantaran sungai yang dijadikan permukiman oleh Masyarakat Berpenghasilan Rendah (MBR) adalah bantaran Sungai Ciliwung. Menurut sumber Dinas Perumahan dan Gedung DKI, jumlah permukiman di bantaran Sungai Ciliwung adalah sebanyak 34.051 KK. Jumlah yang besar mengakibatkan kondisi yang semakin kumuh di bantaran Sungai Ciliwung, menyebabkan penyempitan ekstrim pada DAS. Dalam penanganan bencana banjir Sungai Ciliwung Pemerintah Kota DKI Jakarta mengeluarkan Program Penataan Sungai Ciliwung yaitu Kerangka Kebijakan Permukiman Kembali (KKPK) relokasi hunian, normalisasi sungai, penataan kawasan permukiman dan permukiman kembali. Saat relokasi, terjadi bentrokan fisik warga Kampung Pulo dan Satpol PP yang melakukan pembongkaran hunian di sepanjang bantaran Sungai Ciliwung. Bentrokan fisik menyebabkan hambatan relokasi, pembakaran alat berat pemerintah, korban luka kedua pihak. Metode yang digunakan pada penelitian ini adalah metode kualitatif deskriptif. Penelitian ini membatasi lingkup penelitian di kawasan DAS Ciliwung yaitu Kampung Pulo. Tujuan penelitian untuk mengetahui persepsi masyarakat menolak kebijakan relokasi, mengetahui persepsi masyarakat menerima kebijakan relokasi, permasalahan yang menjadi dasar protes masyarakat terhadap relokasi, mengetahui tingkat keberhasilan relokasi bantaran sungai Ciliwung di Kampung Pulo ke Rusunawa Jatinegara Barat. Selain meneliti dari persepsi masyarakat Kampung Pulo dan warga Rusunawa Jatinegara Barat, penelitian ini juga meneliti persepsi dari pihak Pemerintah Provinsi DKI Jakarta, Dinas Perumahan \& Gedung Pemda DKI/Pengelola Rusunawa Jatinegara Barat, serta Lembaga Swadaya Masyarakat Ciliwung Merdeka. Dari hasil wawancara mendalam dengan masyarakat serta LSM terkait, penolakan masyarakat Kampung Pulo dilatarbelakangi kehilangan hak milik atas tanah dan bangunan, pekerjaan, status sosial, komunikasi sosial antar warga, kehilangan akses umum, ketidakcocokan tinggal di rusun, serta faktor paling dominan adalah kurangnya sosialisasi pemerintah. Alasan masyarakat akhirnya menerima relokasi adalah karena tidak memiliki pilihan lain. Dasar bentrokan fisik yang terjadi antara lain adanya tuntutan ganti rugi atas kerugian tanah maupun bangunan yang tidak dipenuhi oleh Pemerintah Provinsi DKI Jakarta. Karena menurut pemerintah, tanah Kampung Pulo adalah sepenuhnya milik Pemprov DKI Jakarta, sehingga tidak ada dasar untuk mengganti rugi apapun ke masyarakat. Kompensasi yang diberikan pemerintah adalah bantuan dalam bentuk Rusunawa. Walaupun pada akhirnya seluruh warga dapat direlokasi, relokasi Kampung Pulo ke Rusunawa Jatinegara Barat belum bisa dikatakan berhasil, karena dari awal pelaksanaan relokasi sudah mendapatkan penolakan bahkan kerusuhan, serta jumlah masyarakat yang menolak untuk direlokasi lebih banyak daripada yang menerima relokasi.
\end{abstract}

Kata kunci: Relokasi, Bentrokan, Persepsi, Permasalahan Relokasi, Tingkat Keberhasilan Relokasi

\section{PENDAHULUAN}

Peningkatan harga lahan saat ini menyebabkan harga perumahan mengalami peningkatan. Peningkatan ini menyebabkan masyarakat berpenghasilan rendah tidak mampu membeli lahan dan rumah sehingga terpaksa menempati lahan sekitar bantaran sungai, menimbulkan permukiman baru yang keberadaannya padat dan cenderung tumbuh sebagai permukiman kumuh. Permukiman kumuh menurut Yudhohusodo (1997) merupakan kampung atau perumahan liar yang perkembangannya tidak direncanakan terlebih dahulu yang ditempati oleh masyarakat berpenghasilan rendah sampai sangat rendah, memiliki kepadatan penduduk dan kepadatan bangunan tinggi dengan kondisi rumah dan lingkungan yang tidak memenuhi syarat 
kesehatan maupun teknik dengan pola yang tidak teratur, kurangnya prasarana, kurangnya utilitas dan fasilitas sosial.

Salah satu bantaran sungai yang dijadikan permukiman oleh Masyarakat Berpenghasilan Rendah (MBR) adalah bantaran Sungai Ciliwung. Menurut sumber Dinas Perumahan dan Gedung DKI, jumlah permukiman di bantaran Sungai Ciliwung sebanyak 34.051 KK. Jumlah yang besar mengakibatkan kondisi yang semakin kumuh di bantaran Sungai Ciliwung. Akibat peningkatan permukiman di bantaran tersebut, menyebabkan penyempitan ekstrim mencapai 5 meter di aliran Sungai Ciliwung antara lain bantaran sungai di Kampung Melayu, Jakarta Timur, dan Cikini, Jakarta Pusat. Penyempitan tersebut menyebabkan banjir yang cukup parah di kawasan ini.

Dalam upaya penanganan bencana banjir Sungai Ciliwung yang hampir setiap tahun terjadi di permukiman bantaran Sungai Ciliwung yang berfungsi menjadi drainase utama Kota Jakarta, Pemerintah Kota DKI Jakarta mengeluarkan kebijaksanaan melalui Program Penataan Sungai Ciliwung adalah Perda No. 1 tahun 2012 tentang RTRW Jakarta 2030 yang dituangkan dalam konsep skema penanganan yang disebut Resettlement Policy Framework (RPF) atau Kerangka Kebijakan Permukiman Kembali (KKPK) yaitu relokasi hunian, normalisasi Sungai Ciliwung, penataan kawasan permukiman, permukiman kembali. Pelaksanaan relokasi hunian dilakukan melalui kegiatan LARAP (Land Acquisition and Resettlement Action Plan/Rencana Aksi Akuisisi Tanah \& Permukiman Kembali).

Rencana kebijakan Pemerintah Provinsi DKI tentang penataan Sungai Ciliwung dilakukan sejak tahun 2012, pada tahun 2015 kebijakan tersebut dilakukan diawali Kelurahan Kampung Melayu yaitu Kampung Pulo. Saat proses relokasi yaitu tanggal 20 Agustus 2015 dilakukan, terjadi permasalahan yaitu bentrokan fisik warga Kampung Pulo dan Satpol PP yang saat itu akan melakukan pembongkaran bangunan tempat tinggal masyarakat di sepanjang bantaran Sungai Ciliwung. Bentrokan fisik yang terjadi menyebabkan hambatan saat relokasi, pembakaran pada alat-alat berat milik Pemerintah. Setelah Kampung Pulo akan dilakukan penataan dan relokasi pada bantaran Sungai Ciliwung lainnya. Proses relokasi Kampung Pulo dilakukan pada sebanyak 518 Kepala Keluarga (KK) yang tinggal tepat di bantaran Sungai Ciliwung, yang terkena trase perencanaan penataan ke Rusunawa Jatinegara Barat, tetap dilakukan secara bertahap selama satu minggu. Masyarakat yang direlokasi dari Kampung Pulo tersebut dipindahkan ke Rusunawa Jatinegara Barat yang memiliki 2 tower dengan masing-masing tower memiliki 16 lantai. Menara 1 sebanyak 280 unit dan menara 2 sebanyak 266 unit sarusun. Lokasi Rusunawa berada di Jl. Jatinegara Barat Raya, Kel. Kampung Melayu, Kec. Jatinegara, Jakarta Timur dibangun di atas lahan bekas Kantor Dinas Teknis Provinsi DKI Jakarta. Kampung Pulo merupakan permukiman pertama yang dilakukan relokasi di sepanjang bantaran Sungai Ciliwung serta mengalami bentrokan fisik saat relokasi dikarenakan adanya perbedaan pendapat masyarakat dan Pemerintah DKI Jakarta, diambil menjadi studi kasus dalam penelitian ini.

\section{METODE PENELITIAN}

Metode penelitian yang digunakan dalam melakukan penelitian ini adalah metode deskriptif kualitatif dengan pendekatan studi kasus (case study research). Seperti yang disebutkan oleh Yin (1994), bahwa dalam case study research dibutuhkan penyusunan proposisi sebagai dugaan awal terhadap topik penelitian, yang akan diuji berdasarkan temuan lapangan. Untuk menemukan jawaban atas pertanyaan penelitian tentang permasalahan relokasi Kampung Pulo dilakukan berdasarkan teori dampak relokasi permukiman yaitu Asian Development Bank 
(ADB) tentang dampak negatif yang mungkin dapat timbul oleh program relokasi yang tidak direncanakan secara matang dalam pembangunan perkotaan, serta resiko utama dalam pemindahan/relokasi menurut Cernea. Untuk menemukan jawaban atas pertanyaan penelitian mengenai keberhasilan relokasi Kampung Pulo, penelitian dilakukan berdasarkan teori Keberhasilan dan Kegagalan di Pasca Bencana Pemukiman Kembali /Successes and Failures in Post Disaster Resettlement, Anthony Oliver -Smith 1991, Sehingga disusun bahan penelitian yang selanjutnya akan dijadikan bahan pertanyaan di dalam wawancara kepada responden serta analisis hasil penelitian, yaitu:

Tabel 1. Permasalahan Relokasi Berdasarkan Teori Dampak Relokasi

\begin{tabular}{cl}
\hline No & \multicolumn{1}{c}{ Dampak Relokasi } \\
1 & Kehilangan hak milik atas tanah, tempat tinggal \\
2 & Kehilangan pekerjaan/mata pencaharian, Kekurangan Pangan \\
3 & Penurunan status sosial, hilangnya kepercayaan dalam antar masyarakat \\
4 & Penurunan kesehatan dan jumlah kematian \\
5 & $\begin{array}{l}\text { Hilangnya komunikasi social } \\
\text { Kehilangan akses barang dan jasa, akses milik umum dan milik masyarakat (kuburan, }\end{array}$ \\
\hline
\end{tabular}

Tabel 2. Faktor Keberhasilan Relokasi

\begin{tabular}{cl}
\hline No & \multicolumn{1}{c}{ Faktor Keberhasilan Relokasi } \\
1 & Bentuk fisik, perkembangan fisik permukiman baru \\
2 & Pemilihan letak lokasi relokasi \\
3 & Faktor ekonomi \\
4 & Sosialisasi dengan warga yang direlokasi \\
5 & Masyarakat kembali ke lokasi awal \\
\hline
\end{tabular}

Pendekatan yang dilakukan dalam penelitian dampak ini adalah pendekatan kualitatif yang disajikan secara deskripsi. Dalam metode pengumpulan data primer, peneliti menggunakan observasi sendiri untuk melihat dari dekat proses dan masalah yang dulu terjadi dalam program relokasi di Kampung Pulo bantaran Sungai Ciliwung. Wawancara yang dilakukan terhadap beberapa penghuni di Rusunawa Jatinegara dapat berupa incidental dan dapat berupa pilihan. Wawancara mendalam juga dilakukan kepada Dinas Perumahan \& Gedung Pemda DKI/Pengelola Rusunawa Jatinegara Barat, Lembaga Swadaya Masyarakat Ciliwung Merdeka yang terlibat langsung dalam proses sebelum dan saat relokasi sampai setelah relokasi terjadi. serta masyarakat Kampung Pulo dan warga Rusunawa Jatinegara Barat. Dilakukan analisis mengenai persepsi masyarakat menolak kebijakan relokasi, kemudian analisis mengenai persepsi masyarakat menerima kebijakan relokasi, analisis tentang permasalahan yang menjadi dasar protes masyarakat terhadap relokasi permukiman kawasan Kampung Pulo ke Rusunawa Jatinegara Barat. Bagian terakhir adalah analisis tentang tingkat keberhasilan relokasi bantaran Sungai Ciliwung di Kampung Pulo ke Rusunawa Jatinegara Barat. Analisis ini menggunakan dasar teori faktor keberhasilan dan kegagalan relokasi. 
Tabel 3. Narasumber Penelitian

\begin{tabular}{cl}
\hline \multicolumn{1}{c}{ Kriteria } & \multicolumn{1}{c}{ Narasumber } \\
\hline \multirow{2}{*}{ Narasumber Formal } & $\cdot$ Pemerintah Provinsi DKI Jakarta \\
& $\cdot$ Dinas Perumahan \& Gedung Pemda DKI/Pengelola Rusunawa Jatinegara \\
& Lembaga Swadaya Masyarakat \\
\multirow{2}{*}{ Narasumber informal } & $\begin{array}{l}\text { - Penghuni Rusunawa Jatinegara Barat } \\
\end{array}$ \\
\hline
\end{tabular}

\section{HASIL DAN PEMBAHASAN}

\section{A. Analisis Faktor Penolakan Kebijakan Relokasi}

Dari observasi dan wawancara mendalam yang sudah dilakukan ke berbagai pihak yaitu masyarakat penghuni Rusunawa Jatinegara Barat, LSM Ciliwung Merdeka, Pegelola Rusunawa Jatinegara, Pemerintah Provinsi DKI Jakarta dengan pertanyaan-pertanyaan wawancara, kemudian diolah menggunakan analisis deskriptif.

\section{- Faktor Kehilangan Hak Milik Atas Tanah}

Dari hasil temuan lapangan, diketahui bahwa terdapat perbedaan pendapat antara masyarakat Kampung Pulo dan Pemerintah DKI Jakarta mengenai status kepemilikan tanah, yang akhirnya menyebabkan permasalahan yang menjadi dasar penolakan terhadap kebijakan relokasi di Kampung Pulo yaitu tuntutan atas ganti rugi untuk masyarakat atas kehilangan tanah dan bangunan. Pengetahuan masyarakat yang kurang mengenai peraturan tentang penggarapan lahan menyebabkan selama bertahun-tahun menempati Kampung Pulo terutama bantaran Sungai Ciliwung yang seharusnya menjadi sempadan sungai.

Tabel 4 . Persepsi Terhadap Kepemilikan Tanah

\begin{tabular}{|c|c|c|c|}
\hline No & Permasalahan & Tanggapan Masyarakat\&LSM & Tanggapan Pemerintah \\
\hline 1 & $\begin{array}{c}\text { Surat Tanah Kampung } \\
\text { Pulo. }\end{array}$ & $\begin{array}{l}\text { Tidak memiliki SHM (Surat Hak Milik), } \\
\text { hanya memiliki Surat Verponding (Surat } \\
\text { Pemberitahuan Pajak Terhutang Pajak } \\
\text { Bumi dan Bangunan/SPPT-PBB) }\end{array}$ & $\begin{array}{l}\text { Tanpa surat SHM, tanah adalah } \\
\text { sepenuhnya milik Negara. }\end{array}$ \\
\hline 2 & Kawasan Penataan & $\begin{array}{c}\text { Pemerintah akan melakukan sekaligus } \\
\text { "penggusuran" keseluruhan Kampung } \\
\text { Pulo. }\end{array}$ & $\begin{array}{l}\text { Bantaran sungai selebar } 50 \text { meter } \\
\text { sepanjang 4,8 km dari Manggarai } \\
\text { sampai Kampung Melayu }\end{array}$ \\
\hline 3 & Ganti rugi atas tanah & $\begin{array}{c}\text { Pemerintah harus mengganti rugi atas } \\
\text { tanah yang diambil alih untuk } \\
\text { kepentingan Negara. Tanah sudah } \\
\text { diduduki lebih dari } 30 \text { tahun oleh warga } \\
\text { Kampung Pulo. }\end{array}$ & $\begin{array}{c}\text { Tidak ada penggantian kerugian } \\
\text { atas tanah karena tanah tersebut } \\
\text { adalah tanah Negara. }\end{array}$ \\
\hline 4 & $\begin{array}{c}\text { Ganti rugi atas } \\
\text { bangunan }\end{array}$ & $\begin{array}{l}\text { Pemerintah seharusnya mengganti } \\
\text { kerugian bangunan yang dibangun } \\
\text { menggunakan uang warga sendiri. }\end{array}$ & $\begin{array}{l}\text { Pemerintah hanya mengambil } \\
\text { kembali lahan negara, } \\
\text { menyediakan Rusunawa } \\
\text { Jatinegara Barat sebagai } \\
\text { kompensasi bagi masyarakat. }\end{array}$ \\
\hline
\end{tabular}




\section{- Faktor Kehilangan Pekerjaan/Mata Pencaharian Serta Kekurangan Pangan}

Tabel 5. Persepsi Terhadap Kehilangan Mata Pencaharian

\begin{tabular}{llll}
\hline No & \multicolumn{1}{c}{ Permasalahan } & \multicolumn{1}{c}{ Tanggapan Masyarakat\&LSM } & \multicolumn{1}{c}{ Tanggapan Pemerintah } \\
\hline 1 & Kehilangan Pekerjaan & $\begin{array}{l}\text { Tidak dapat melakukan kegiatan } \\
\text { perekonomian seperti sedia kala } \\
\text { karena keterbatasan ruang di } \\
\text { Rusunawa Jatinegara Barat. }\end{array}$ & $\begin{array}{l}\text { Disediakan tempat berdagang, } \\
\text { gerobak, kursi untuk berdagang } \\
\text { secara gratis. }\end{array}$ \\
$\begin{array}{llll}\text { Penambahan pengeluaran } \\
\text { untuk membayar sewa } \\
\text { rusun }\end{array}$ & $\begin{array}{l}\text { Di Kampung Pulo tidak perlu } \\
\text { membayar sewa, listrik dan air. } \\
\text { Semua gratis. }\end{array}$ & $\begin{array}{l}\text { Sistem pembayaran sewa } \\
\text { Rusunawa diberikann } \\
\text { kompensasi keringanan berupa } \\
\text { cicilan melalui Bank DKI. }\end{array}$ \\
& & $\begin{array}{l}\text { Warga juga diberikan fasilitas } \\
\text { gratis seperti busway gratis } \\
\text { untuk Jabodetabek, pengobatan } \\
\text { dan dokter gratis, Paud, } \\
\text { perpustakaan, dll }\end{array}$ \\
\hline
\end{tabular}

- Faktor Penurunan Status Sosial, Hilangnya Kepercayaan Antar Masyarakat Tabel 6. Persepsi Terhadap Kehilangan Status Sosial

\begin{tabular}{|c|c|c|c|}
\hline No & Permasalahan & Tanggapan Masyarakat\&LSM & Tanggapan Pemerintah \\
\hline 1 & $\begin{array}{l}\text { Kehilangan jabatan setelah } \\
\text { di rusun }\end{array}$ & $\begin{array}{l}\text { Pemilihan kembali Ketua RT karena } \\
\text { sekarang warga sudah bercampur } \\
\text { setiap lantai, sehingga sulit untuk } \\
\text { menentukan siapa saja yang } \\
\text { dahulunya adalah tokoh masyarakat. }\end{array}$ & $\begin{array}{l}\text { Perlu adanya pemilihan Ketua } \\
\text { RT sebagai media koordinasi } \\
\text { antar warga di Rusunawa } \\
\text { Jatinegara Barat. }\end{array}$ \\
\hline 2 & $\begin{array}{l}\text { Hilangnya kepercayaan } \\
\text { antar warga }\end{array}$ & $\begin{array}{l}\text { Seluruh warga berganti tetangga, } \\
\text { komunikasi bisa berkurang antar } \\
\text { warga dan rasa percaya belum } \\
\text { terjalin. }\end{array}$ & $\begin{array}{l}\text { Setiap unit rusun berhadap- } \\
\text { hadapan setiap kamar, } \\
\text { sehingga perlu adanya } \\
\text { komunikasi antar warga. }\end{array}$ \\
\hline
\end{tabular}

\section{- Faktor Penurunan Kesehatan dan Peningkatan Kematian}

\section{Tabel 7. Persepsi Terhadap Penurunan Kesehatan}

\begin{tabular}{clll}
\hline No & Permasalahan & Tanggapan Masyarakat\&LSM & Tanggapan Pemerintah \\
\hline 1 & $\begin{array}{l}\text { Trauma, Stres dan } \\
\text { penyakit lain }\end{array}$ & $\begin{array}{l}\text { Sempat merasakan stres karena } \\
\text { melihat langsung pembongkaran } \\
\text { rumah, konflik secara langsung serta } \\
\text { relokasi yang terkesan dipaksa. }\end{array}$ & $\begin{array}{l}\text { Berdasarkan data penduduk, } \\
\text { yang pindah ke Rusunawa } \\
\text { sesuai dengan jumlah } \\
\text { penduduk relokasi Kampung } \\
\text { Pulo. }\end{array}$ \\
& Kelayakan hunian & $\begin{array}{l}\text { Lebih bagus dan layak di Rusunawa } \\
\text { Jatinegara, tidak banjir dan } \\
\text { lingkungan sehat }\end{array}$ & $\begin{array}{l}\text { Rusunawa Jatinegara Barat } \\
\text { lebih layak untuk manusia } \\
\text { daripada bantaran sungai } \\
\text { Ciliwung di Kampung Pulo, } \\
\text { tidak banjir dan air bersih. }\end{array}$ \\
\hline
\end{tabular}




\section{- Faktor Komunikasi Sosial Antara Warga}

Tabel 8. Persepsi Terhadap Komunikasi Antar Warga

\begin{tabular}{clll}
\hline No & \multicolumn{1}{c}{ Permasalahan } & \multicolumn{1}{c}{ Tanggapan Masyarakat\&LSM } & Tanggapan Pemerintah \\
\hline 1 & Hilangnya komunikasi & Pada awalnnya sangat individual. & Pemerintah berusaha \\
& sosial, kegiatan rutin & Mengalami peningkatan sejak & mengembalikan kondisi \\
& sosial & dilakukan banyak kegiatan sosial & sosial yang sempat rusak \\
& dan acara bersama. & dengan mengadakan \\
& & banyak kegiatan di \\
& & & Rusunawa Jatinegara \\
& & & Barat. \\
\hline
\end{tabular}

\section{- $\quad$ Faktor Kehilangan Akses Pribadi dan Umum}

Tabel 9. Persepsi Terhadap Kehilangan Akses Pribadi dan Umum

\begin{tabular}{clll}
\hline No & \multicolumn{1}{c}{ Permasalahan } & \multicolumn{1}{c}{ Tanggapan Masyarakat\&LSM } & \multicolumn{1}{c}{ Tanggapan Pemerintah } \\
\hline 1 & Kehilangan akses ke & Sungai Ciliwung selama ini & Bantaran Sungai \\
& Sungai Ciliwung & dimanfaatkan untuk kepentingan & berfungsi sebagai \\
& & sehari-hari. Masyarakat terbiasa & sempadan Sungai sesuai \\
& dengan pemanfaatan air sungai & Peraturan Pemerintah \\
& sebagai mata pencaharian. & Nomor 38 Tahun 2011. \\
\hline
\end{tabular}

- $\quad$ Faktor Bentuk dan Perkembangan Fisik Rusunawa Jatinegara Barat

Tabel 10. Persepsi Terhadap Bentuk Fisik Rusun

\begin{tabular}{|c|c|c|c|}
\hline No & Permasalahan & $\begin{array}{c}\text { Tanggapan } \\
\text { Masyarakat\&LSM }\end{array}$ & Tanggapan Pemerintah \\
\hline 1 & $\begin{array}{l}\text { Kesesuaian rusun } \\
\text { sebagai tempat } \\
\text { relokasi }\end{array}$ & $\begin{array}{l}\text { Masyarakat Kampung Pulo } \\
\text { terbiasa dengan kehidupan } \\
\text { di bantaran sungai, dengan } \\
\text { rumah menapak pada } \\
\text { tanah. }\end{array}$ & $\begin{array}{l}\text { Rusun solusi terbaik } \\
\text { kompensasi buat warga } \\
\text { bantaran sungai, lebih layak } \\
\text { dan manusiawi. }\end{array}$ \\
\hline 2 & $\begin{array}{l}\text { Aspek nilai budaya } \\
\text { dalam menentukan } \\
\text { hunian baru }\end{array}$ & $\begin{array}{l}\text { Pemerintah seharusnya } \\
\text { mempertbangkan nilai } \\
\text { historis dari Kampung } \\
\text { Pulo. }\end{array}$ & $\begin{array}{l}\text { Bantaran sungai yang harus } \\
\text { dikosongkan karena bisa } \\
\text { menyebabkan banjir. }\end{array}$ \\
\hline 3 & $\begin{array}{l}\text { Ide masyarakat } \\
\text { "Kampung Susun" } \\
\text { sebagai alternatif } \\
\text { tujuan relokasi }\end{array}$ & $\begin{array}{l}\text { Warga tidak perlu digusur } \\
\text { dan dipindahkan namun } \\
\text { dilakukan sesuai aspirasi } \\
\text { warga, bukan penggusuran } \\
\text { namun merevitalisasi } \\
\text { kampung }\end{array}$ & $\begin{array}{l}\text { Tetap tidak bisa dilakukan } \\
\text { karena bantaran sungai harus } \\
\text { kosong. }\end{array}$ \\
\hline
\end{tabular}




\section{- $\quad$ Faktor Pemilihan Letak Lokasi Rusunawa Jatinegara Barat}

Tabel 11. Persepsi Terhadap Letak Lokasi Rusun

\begin{tabular}{|c|c|c|c|c|c|}
\hline No & \multicolumn{2}{|c|}{ Permasalahan } & \multicolumn{2}{|c|}{ Tanggapan Masyarakat\&LSM } & Tanggapan Pemerintah \\
\hline 1 & \multicolumn{2}{|c|}{$\begin{array}{l}\text { Jarak dari lokasi semula } \\
\text { (Kampung Pulo) }\end{array}$} & \multicolumn{2}{|c|}{$\begin{array}{l}\text { Dekat dengan lokasi semula } \\
\text { sehingga tidak terlalu sulit untuk } \\
\text { akses pindah, dekat untuk } \\
\text { mengunjungi saudara yang masih } \\
\text { di Kampung Pulo }\end{array}$} & $\begin{array}{l}\text { Rusunawa Jatinegara adalah } \\
\text { rusun yang paing dekat } \\
\text { dengan lokasi semula } \\
\text { dibandingkan dengan rusun- } \\
\text { rusun lain. }\end{array}$ \\
\hline 2 & \multicolumn{2}{|c|}{$\begin{array}{l}\text { Aksesibilitas terhadap fasilitas } \\
\text { transportasi, kesehatan, } \\
\text { pendidikan, perkantoran, } \\
\text { perbelanjaan, tempat ibadah. }\end{array}$} & \multicolumn{2}{|c|}{$\begin{array}{l}\text { Strategis, mudah dicapai dari } \\
\text { segala arah dan segala fasilitas } \\
\text { dekat. }\end{array}$} & $\begin{array}{l}\text { Strategis, mudah dicapai dari } \\
\text { segala arah dan segala } \\
\text { fasilitas dekat. }\end{array}$ \\
\hline \multicolumn{6}{|c|}{ Faktor Sosialisasi Relokasi } \\
\hline \multicolumn{6}{|c|}{ Tabel 12. Persepsi Terhadap Letak Lokasi Rusun } \\
\hline No & Permasalahan & Tangga & Masyarakat\&LSM & & nggapan Pemerintah \\
\hline 1 & $\begin{array}{l}\text { Sosialisasi } \\
\text { tetang relokasi }\end{array}$ & $\begin{array}{l}\text { Masyara } \\
\text { yang dil } \\
\text { penyam } \\
\text { jarang } \mathrm{n} \\
\text { Warga } n \\
\text { kebanya }\end{array}$ & $\begin{array}{l}\text { merasa sosialisasi } \\
\text { ukan hanya berupa } \\
\text { an informasi dan } \\
\text { ibatkan warga. } \\
\text { adapatkan info } \\
\text { n melalui LSM }\end{array}$ & $\begin{array}{l}\text { Sudah dilakul } \\
\text { seringkali tid } \\
\text { mengatakan b } \\
\text { karena dari a }\end{array}$ & $\begin{array}{l}\text { kan sosialisasi namun warga } \\
\text { k hadir dan kemudian } \\
\text { ahwa tidak adanya relokasi } \\
\text { val sudah menolak relokasi. }\end{array}$ \\
\hline 2 & $\begin{array}{l}\text { Sosialisasi } \\
\text { status lahan }\end{array}$ & $\begin{array}{l}\text { Tidak p } \\
\text { kepemil } \\
\text { berangg } \\
\text { adalah } n\end{array}$ & $\begin{array}{l}\text { Im tentang tata cara } \\
\text { an lahan, hanya } \\
\text { an bahwa lahan } \\
\text { ik warga. }\end{array}$ & $\begin{array}{l}\text { Pemerintah } \mathrm{m} \\
\text { memberikan } 1 \\
\text { tentang tata } \mathrm{c}\end{array}$ & $\begin{array}{l}\text { iemang belum informatif dalam } \\
\text { oimbingan kepada masyarakat } \\
\text { ara kepengurusan lahan. }\end{array}$ \\
\hline 3 & $\begin{array}{l}\text { Sosialisasi } \\
\text { ganti rugi }\end{array}$ & $\begin{array}{l}\text { Masyara } \\
\text { menden } \\
\text { kemudia } \\
\text { diganti } r \\
\text { dasar pe }\end{array}$ & $\begin{array}{l}\text { awalnya } \\
\text { akan diganti rugi, } \\
\text { dinyatakan tidak } \\
\text { i, tanpa mengetahui } \\
\text { lakan ganti rugi. }\end{array}$ & $\begin{array}{l}\text { Warga kurang } \\
\text { Pemerintah se } \\
\text { diganti rugi. I } \\
\text { juga pada aw } \\
\text { sosialisasi tid } \\
\text { rugi sebelum }\end{array}$ & $\begin{array}{l}\text { parsitipatif dalam sosialisasi } \\
\text { hingga selalu berpikir akan } \\
\text { Pemerintah mengakui bahwa } \\
\text { alnya seharusnya di awal } \\
\text { ak langsung menyatakan ganti } \\
\text { analisis lebih lanjut. }\end{array}$ \\
\hline
\end{tabular}




\section{B. Analisis Faktor Penolakan Kebijakan Relokasi}

\section{- Alasan Masyarakat Menolak Relokasi}

Dari seluruh analisis yang telah dilakukan bisa diidentifikasi bahwa alasan masyarakat bantaran Sungai Ciliwung Kampung Pulo menolak kebijakan relokasi:

Tabel 13. Faktor Penolakan Relokasi

\begin{tabular}{|c|c|c|}
\hline No & & san Menolak Relokasi \\
\hline 1 & $\begin{array}{l}\text { Akan kehilangan hak milik atas } \\
\text { tanah dan bangunan. }\end{array}$ & $\begin{array}{l}\text { Merasa memiliki sertifikat tanah resmi } \\
\text { Sudah lama menempati Kampung Pulo } \\
\text { Memiliki bangunan rumah }\end{array}$ \\
\hline 2 & $\begin{array}{l}\text { Akan kehilangan pekerjaan/mata } \\
\text { pencaharian }\end{array}$ & $\begin{array}{l}\text { Biasanya menggunakan rumah sebagai tempat bekerja } \\
\text { untuk usaha rumahan } \\
\text { Bertambahnya pengeluaran bayar sewa rusun } \\
\text { Kehilangan tempat berdagang dan pelanggan }\end{array}$ \\
\hline 3 & $\begin{array}{l}\text { Akan kehilangan status sosial dan } \\
\text { kenyamanan bertetangga }\end{array}$ & $\begin{array}{l}\text { Pergantian jabatan setelah di rusun seperti : Ketua RT } \\
\text { Merasa nyaman dengan tetangga rumah, saling } \\
\text { ketergantungan antar warga }\end{array}$ \\
\hline 4 & $\begin{array}{l}\text { Kehilangan komunikasi sosial antar } \\
\text { warga }\end{array}$ & $\begin{array}{l}\text { Sudah terbentuk kegiatan dan interaksi sosial di } \\
\text { Kampung Pulo } \\
\text { Sudah nyaman dengan komunitas sosial masing-masing } \\
\text { Terpisah dari keluarga yang tidak terkena penataan } \\
\text { kawasan di Kampung Pulo }\end{array}$ \\
\hline 5 & Kehilangan akses umum & $\begin{array}{l}\text { Pemanfaatan Sungai Ciliwung untuk kehidupan sehari- } \\
\text { hari } \\
\text { Kebiasaan hidup di bantaran sungai serta sumber mata } \\
\text { pencaharian }\end{array}$ \\
\hline 6 & $\begin{array}{l}\text { Kecocokan rusun sebagai tempat } \\
\text { tinggal yang baru }\end{array}$ & $\begin{array}{l}\text { Sudah terbiasa hidup di rumah yang menapak ke tanah } \\
\text { dan memiliki halaman } \\
\text { Tidak terbiasa menggunakan lift } \\
\text { Sudah terbentuk budaya di Kampung Pulo, memiliki } \\
\text { nilai sejarah bagi warga. } \\
\text { Keberatan harus menyewa rusun } \\
\text { Sudah merasa nyaman di Kampung Pulo walaupun } \\
\text { banjir }\end{array}$ \\
\hline 7 & Sosialisasi & $\begin{array}{l}\text { Kurangnya pemahaman tentang kerugian dan } \\
\text { keuntungan relokasi, serta UU pertanahan } \\
\text { Salah paham akan luas kawasan penataan } \\
\text { Tuntutan ganti rugi yang tidak dipenuhi }\end{array}$ \\
\hline
\end{tabular}




\section{- Alasan Masyarakat Menerima Relokasi}

Tabel 14. Faktor Penerimaan Relokasi

\begin{tabular}{|c|c|c|}
\hline No & Alasan Men & rima Relokasi \\
\hline 1 & Lebih bersih dan aman dari banjir & $\begin{array}{l}\text { Rumah di Kampung Pulo kotor dan selalu terkena } \\
\text { banjir } \\
\text { Lebih sehat karena air lebih bersih } \\
\text { Lingkungan lebih bersih dan sehat }\end{array}$ \\
\hline 2 & $\begin{array}{l}\text { Letak lokasi Rusunawa Jatinegara } \\
\text { Barat }\end{array}$ & $\begin{array}{l}\text { Dekat dengan lokasi awal Kampung Pulo } \\
\text { Strategis mudah dicapai } \\
\text { Kedekatan dengan fasilitas transportasi, } \\
\text { kesehatan,perbelanjaan, perkantoran } \\
\text { Jarak sekolah masih dekat seperti di Kampung Pulo }\end{array}$ \\
\hline 3 & Hunian lebih layak & $\begin{array}{l}\text { Kondisi bangunan yang lebih bagus dan layak } \\
\text { Kondisi rumah yang lebih buruk saat di Kampung Pulo }\end{array}$ \\
\hline 4 & Tidak memiliki pilihan lain & $\begin{array}{l}\text { Kondisi rumah yang sudah hancur } \\
\text { Tidak memiliki rumah lain selain di Kampung Pulo } \\
\text { Takut hidup terlantar jika tidak memilih rusun }\end{array}$ \\
\hline
\end{tabular}

C. Analisis Permasalahan yang Menjadi Dasar Protes dan Konflik

- Kurangnya partisipasi masyarakat dalam perencanaan relokasi Kampung Pulo ke Rusunawa Jatinegara Barat.

- Tuntutan ganti rugi atas kerugian tanah maupun bangunan yang tidak dipenuhi oleh Pemerintah Provinsi DKI Jakarta.

- Kehilangan akses ke Sungai Ciliwung

\section{Analisis Tingkat Keberhasilan Relokasi Kampung Pulo}

Analisis yang telah dilakukan tentang teori faktor-faktor keberhasilan relokasi di Kampung Pulo berdasarkan observasi dan wawancara antara lain: 


\section{Tabel 15. Analisis Tingkat Keberhasilan Relokasi}

\begin{tabular}{|c|c|c|}
\hline No & Faktor Keberhasilan Relokasi & Hasil Analisis \\
\hline 1 & $\begin{array}{l}\text { Bentuk fisik dan perkembangan } \\
\text { fisik hunian yang baru }\end{array}$ & $\begin{array}{l}\text { Masyarakat merasa kurang nyaman dengan hunian tinggi } \\
\text { karena terbiasa dengan hunian tapak. Namun pada akhirnya } \\
\text { masyarakat mulai membiasakan diri dan beradaptasi dengan } \\
\text { baik. }\end{array}$ \\
\hline 2 & $\begin{array}{l}\text { Pemilihan lokasi permukiman yang } \\
\text { baru }\end{array}$ & $\begin{array}{l}\text { Rusunawa Jatinegara Barat memiliki lokasi yang dekat lokasi } \\
\text { lama yaitu } 1,3 \mathrm{~km} \text { dari Kampung Pulo dan posisi strategis, } \\
\text { aksesibilitas terhadap fasilitas transportasi, kesehatan, } \\
\text { pendidikan, perkantoran,perbelanjaan, tempat ibadah, mudah } \\
\text { dicapai dari segala arah. Masyarakat mudah dalam melakukan } \\
\text { aktivitas sehari-hari. }\end{array}$ \\
\hline 3 & Perubahan ekonomi masyarakat & $\begin{array}{l}\text { Adanya perubahan ekonomi setelah direlokasi, masyarakat } \\
\text { yang kehilangan pekerjaan sekitar } 9.4 \% \text { dan ditambah } \\
\text { pengeluaran biaya sewa rusun. Pemerintah menyediakan } \\
\text { tempat berdagang namun belum difungsikan sepenuhnya oleh } \\
\text { warga rusun. }\end{array}$ \\
\hline 4 & $\begin{array}{l}\text { Sosialisasi Pemerintah dengan } \\
\text { masyarakat }\end{array}$ & $\begin{array}{l}\text { Sosialisasi yang dilakukan dinilai kurang karena masyarakat } \\
\text { merasa tidak dilibatkan dalam rencana relokasi, masyarakat } \\
\text { tidak paham mengenai Undang-Undang kepemilikan lahan, } \\
\text { adanya tuntutan ganti rugi terhadap lahan dan bangunan yang } \\
\text { pada akhirnya melakukan perlawanan saat relokasi terjadi. }\end{array}$ \\
\hline 5 & $\begin{array}{l}\text { Masyarakat kembali ke } \\
\text { permukiman semula }\end{array}$ & $\begin{array}{l}\text { Adanya keinginan masyarakat untuk kembali ke permukiman } \\
\text { semula, karena terbiasa hidup di Kampung Pulo dan beban } \\
\text { sewa Rusunawa Jatinegara Barat. Tetapi sampai saat ini } \\
\text { belum ada masyarakat yang kembali ke permukiman semula } \\
\text { di Kampung Pulo, masih 100\% tinggal di Rusunawa } \\
\text { Jatinegara Barat. }\end{array}$ \\
\hline 6 & $\begin{array}{l}\text { Jumlah masyarakat yang menolak } \\
\text { sejak awal relokasi dibandingkan } \\
\text { dengan jumlah masyarakat yang } \\
\text { menerima relokasi }\end{array}$ & $\begin{array}{l}\text { Dari } 100 \% \text { masyarakat yang direlokasi, Jumlah masyarakat } \\
\text { yang menolak direlokasi } 89 \% \text {, yang menerima relokasi yaitu } \\
11 \% \text {. }\end{array}$ \\
\hline
\end{tabular}

Dari temuan di lapangan, penerapan kebijakan relokasi ini belum bisa dikatakan berhasil bahkan cenderung gagal. Hal tersebut dapat dilihat dari hal-hal berikut:

a. Warga yang menolak hampir keseluruhan warga bantaran Kampung Pulo, dari 518 KK hanya ada $60 \mathrm{KK}$ yang bersedia pindah ke Rusunawa Jatinegara tanpa melakukan bentrokan fisik dengan Pemerintah.

b. Warga yang dipindahkan mendapatkan dampak yang cukup signifikan yaitu kehilangan pekerjaan sekitar 9,4\%. Adanya fasilitas berdagang di Rusunawa Jatinegara ternyata belum dimanfaatkan sepenuhnya oleh warga penghuni rusun. Karena sebagian warga pada awalnya bukan pedagang dengan gerobak dagang. Warga menjadikan rumah sebagai pabrik memproduksi barang.

c. Adanya perlawanan berupa bentrokan fisik oleh masyarakat terhadap pelaksanaan relokasi, dikategorikan sebagai kegagalan relokasi (Smith 1991) 


\section{KESIMPULAN}

Permasalahan yang menjadi dasar protes masyarakat terhadap relokasi tersebut adalah kurangnya partisipasi dan aspirasi masyarakat melalui sosialisasi dalam perencanaan relokasi Kampung Pulo ke Rusunawa Jatinegara Barat, tuntutan ganti rugi atas kerugian tanah maupun bangunan yang tidak dipenuhi oleh Pemerintah Provinsi DKI Jakarta, serta kehilangan akses bantaran Sungai Ciliwung. Sejauh ini relokasi Kampung Pulo ke Rusunawa Jatinegara dikategorikan sebagai relokasi yang gagal karena mendapat penolakan oleh masyarakat di awal pelaksanaan relokasi walaupun akhirnya setelah seluruh bangunan berhasil dibongkar, warga akhirnya bersedia direlokasi.

Masyarakat bantaran Sungai Ciliwung menolak kebijakan relokasi Kampung Pulo ke Rusunawa Jatinegara Barat dengan alasan:

a. kehilangan hak milik tanah dan bangunan.

b. kehilangan pekerjaan/mata pencaharian

c. kehilangan status sosial dan kenyamanan bertetangga

d. Kekhawatiran kehilangan komunikasi antar warga

e. kehilangan akses umum

f. Ketidakcocokan rusun bagi masyarakat

g. Sosialiasi Pemerintah dan Masyarakat Dianggap Kurang Maksimal

Masyarakat bantaran Sungai Ciliwung menerima kebijakan relokasi Kampung Pulo ke Rusunawa Jatinegara Barat dengan alasan:

a. Sudah tidak memiliki pilihan lain.

b. Rusunawa Jatinegara Barat lebih bersih dan aman dari banjir

c. Letak lokasi Rusunawa Jatinegara Barat

Analisis Permasalahan yang Menjadi Dasar Protes Masyarakat Terhadap Relokasi Permukiman Kawasan Kampung Pulo ke Rusunawa Jatinegara Barat:

a. Kurangnya partisipasi masyarakat dalam perencanaan relokasi Kampung Pulo ke Rusunawa Jatinegara Barat.

b. Adanya tuntutan ganti rugi atas kerugian tanah maupun bangunan yang tidak dipenuhi oleh Pemerintah Provinsi DKI Jakarta.

c. Kehilangan akses ke Sungai Ciliwung

Tingkat Keberhasilan Relokasi Bantaran Sungai Ciliwung di Kampung Pulo ke Rusunawa Jatinegara Barat belum bisa dikatakan berhasil, karena dari awal pelaksanaan relokasi sudah mendapatkan penolakan dari masyarakat yang akan direlokasi (Smith, 1991). Sehingga relokasi ini termasuk relokasi paksa (involuntary resettlement). Walaupun pada akhirnya masyarakat Kampung Pulo menerima untuk direlokasi karena hampir seluruhnya warga mengaku sudah tidak ada pilihan lain. Warga yang menolak untuk direlokasi lebih banyak daripada yang menerima relokasi. Dari 517 KK yang direlokasi hanya sekitar $60 \mathrm{KK}$ yang bersedia direlokasi tanpa bentrokan. Persentase penolakan relokasi sekitar $89 \%$ dari keseluruhan jumlah warga yang direlokasi. Sedangkan persentase penerimaan relokasi sekitar $11 \%$ dari keseluruhan jumlah warga yang direlokasi. 


\section{UCAPAN TERIMA KASIH (Acknowledgement)}

Penulis menyampaikan ucapan terima kasih kepada Ibu Dr. Ir. Nurahma Tresani, M.P.M. dan Ibu Dr. Ir. Lana Winayanti, MCP selaku dosen pembimbing yang telah memberikan bimbingan, bantuan, dan arahan kepada penulis.

\section{REFERENSI}

Adi, W. (2016, April 22). Dulu Ikon Banjir, Kini Kampung Pulo Bebas Banjir. Kompas. Diunduh dari http://megapolitan.kompas.com/read/2016/04/22/07170501/Dulu.Ikon.Banjir.Kini.Kam pung.Pulo.Bebas.Banjir

Asian Development Bank. (2002). Handbook on resettlement: A guide to good practice. Manila, Phillipines: ADB

Belarminus, R. (2016, Maret 8). Setelah dinormalisasi, begini situasi kampung pulo saat banjir. Kompas. Diunduh dari http://megapolitan.kompas.com/read/2016/03/08/09511521/Setelah.Dinormalisasi.Begin i.Situasi.Kampung.Pulo.Saat.Banjir.

Oliver, A., \& Smith. (1991). Successes and failures in post disaster resettlemet disaster. The Journal of Disaster Studies and Management,.15(1).

Cernea, M, M. (1998, October). Impoverishment risk, risk management, and reconstruction: A model of population displacement and resettlement. In M. M. Cernea (Chair), Hydropower and sustainable development. Symposium conducted at the UN Washington, DC.

Dewi, A., Ratna, A., Syahrani. (2014). Persepsi Masyarakat Terhadap Kebijakan Relokasi Penduduk Bantaran Sungai Karangmumus Samarinda Kalimantan Timur. Surabaya.

Pembangunan Rusunawa dan Rusunami di DKI Jakarta. Dinas Perumahan Provinsi DKI Jakarta Tahun Anggaran (2006)

Kementerian Sosial Republik Indonesia tentang Rencana Penanganan Daerah Aliran Sungai Ciliwung.

Laras, Hartono (2012). Rencana Penanganan DAS Ciliwung, Kementerian Sosial Republik Indonesia

Pedoman Teknis Pembangunan Rumah Susun Sederhana Bertingkat Tinggi. Peraturan Menteri Pekerjaan Umum Nomor: 05/PRT/M/2007 (2007)

Pembangunan Rumah Susun Sederhana. Peraturan Gubernur DKI Jakarta Nomor 27 Tahun (2009)

Rencana Tata Ruang Wilayah 2030. Peraturan Daerah DKI Jakarta Nomor 1 Tahun (2012)

Pedoman Pemberian Santunan Kepada Penggarap Tanah Negara. Peraturan Gubernur DKI Jakarta Nomor 190 (2014)

Perumahan dan Kawasan Permukiman. Undang-undang Republik Indonesia Nomor 1 Tahun (2011)

Rencana Tata Ruang Wilayah 2030. Peraturan Daerah DKI Jakarta Nomor 1 Tahun (2012) Sungai.Undang-undang Republik Indonesia Nomor 38 Tahun (2011)

Susanto, Y. (2016). Dampak Sosial Ekonomi Masyarakat Bantaran Sungai Pasca Permukiman Kembali ke Rusunawa. Jakarta.

Undang-undang Republik Indonesia Nomor 20 Tahun 2011 tentang Rumah Susun (UU Rumah Susun) pengganti Undang-undang Republik Indonesia Nomor 16 Tahun 1985. 